\title{
Analysis and Discussion on Major Technology Ability of Safety Engineering

\author{
Jian-Fang ZHU ${ }^{1, a}$, Ji LI ${ }^{1, b}$, Guo-Xing LIU ${ }^{1, c}$ and Zhi-Liang WANG ${ }^{1, d}$
} \\ ${ }^{1}$ School of Safety Engineering, North China Institute of Science and Technology, Beijing \\ abj_zjf@126.com, ${ }^{b}$ liji100@126.com, ${ }^{\mathrm{c}} \mathrm{g}$ x1010@ncist.edu.cn, ${ }^{\mathrm{d}}$ wzl@ncist.edu.cn \\ *Jian-Fang ZHU
}

Keywords: Safety engineering, major technology ability, training practical talents, personnel training plan.

\begin{abstract}
The training of applied talents is the requirement of the development of our national economy. According to the requirement, this paper analyzes the characteristics of safety engineering discipline in China and cross discipline, discusses the safety engineering discipline development three stages of transformation which are composed of "industry security" to "general safety" stage, from "general safety" to "industry safety" stage, and now relying on "industry safety" and taking into account "general safety" stage. On this basis, the technical ability of safety engineering specialty is summarized as "general safety" professional skills and "industry safety" professional skills, among them "general safety" professional skills including hazard identification assessment control ability, safety inspection ability, designing ability of safety technical measures, safety engineering design capability, safety management ability, accident emergency rescue ability and investigation and treatment capacity. "The industry security" professional and technical ability use the coal industry as an example to the summary, divided into safety inspection ability, designing ability of technical measures, technical data processing and analysis ability, ability of engineering design, the emergency response capacity and other professional capability, a total of six categories, each category include many specific abilities behind. It is very important and positive significance for training applied talents, through the analysis of the demand of safety engineering professional and technical ability.
\end{abstract}

\section{Introduction}

In China, both the number of safety production accidents and the deaths have been decreasing gradually in recent years, but it is still possible to take place for certain fatal accidents. It means that the situation of safety production is still severe, which not only requires to improve the safety awareness of people nationwide, but also to strengthen the accident prevention ability of enterprises and institutions nationwide. Meanwhile, it puts forward further requirements for the training of bright people skilled in safety production, especially the training of applied talents. The cultivation of applied talents is one of the most direct embodiments of the function that higher education institution contributes to society. In China, that colleges and universities should set strong awareness of serving society actively and launch the full range of services has been put forward clearly in the Outline of National Medium-and Long-Term Program for Education Reform and Development (2010-2020), which also requires that it should optimize the discipline, the type and the level structure and expand cultivation scale of the applied, compound, skilled talents. Thus, the country has 
carried on the plan to the training of applied talents from the strategic level. As the college belonging to State Administration of Work Safety and training safety production talents for the nation, it is more obvious that the responsibility of implement the plan is unshirkable.

The training of applied talents requires students must have the solid major technology ability. The demand analysis of the talents major technology ability is the foundation of making the talents training plan. So the demand of the technical ability of safety engineering is discussed initially in the paper. Of course, the demand for training talents has a number of aspects, in addition to major technology ability, other skills such as international communication skills, critical thinking ability, etc. are also important,. The paper only analyzes the professional and technical ability.

\section{Development and Characteristics Analysis on Safety Engineering Discipline}

The main task of safety engineering discipline is studying the various disasters and control technology in the production and social activities of human beings to ensure people's physical and mental health and life safety and to prevent or reduce the loss of material wealth. When it comes to safety engineering discipline, there are generally "industry security" and "general safety". The research object of the so-called "industry security" is a national economy industry or a field of security such as coal mine safety, chemical safety, food safety or traffic safety, etc. The employment range that the graduates of "industry security" is mainly in the industry. But the research object of "general safety" is the common security problem in all industries and fields. That is to say, "general safety" extract and research the common problems in various fields involved in security. So its graduates can be employed in all sectors of the field. The development of safety engineering discipline roughly experienced three development stages of transformation as follows.

The first stage: The development stage from "industry safety" to "general safety". Take the colleges and universities belonging to the Ministry of Coal as example, such as China University of Mining and Technology, Xi'an University of Science and Technology, etc. In the early 1980s, these colleges and universities set up "mine ventilation and security" discipline, one of the predecessors of the safety engineering discipline. At that time, the students of this profession were mainly assigned to coal mines all over the country and engaged in coal mine ventilation safety technology and management after graduation. However, from the early 1990s the higher education system reformed and colleges and universities began to charge tuition fees. Students' employment was no longer subject to the constraints of the system. Besides, the graduates were unwilling to work in coal mines because the coal industry's sharp losses in the middle of the 90s and coal mine workers' wages were universal low. That the students' employment situation was unsatisfactory affected the enrollment work of these professions greatly. So each university conducted a comprehensive adjustment from setting the profession training goal to installing the curriculum system to expand the employment channels for students. The main direction of the adjustment was the development from the "industry security" to the "generic security " areas. That was also developing to the "general safety". It greatly promoted the covering surface of safety engineering discipline. It could be said it directly promote the molding of "general safety view". This is the stage from "industry security" to "general safety" as previously described.

The second stage: the stage from "general safety" to "industry safety". The development process of part colleges and universities under the guidance of "general safety" thinking also appeared some problems. Firstly, it was necessary to set up the new curriculums and enrich 
the corresponding teaching conditions due to getting involved into new areas. This aspect of teaching resources and teaching conditions including qualification of teachers experimental conditions and so on were reserved inadequately. It took time and money to get; it could not be achieved overnight. On the other hand, some colleges also planned to extend the research direction to other industries through opening up new teaching field. However, the effect of this aspect was not obvious after the development of a few years. The last and major aspect was that the students under the cultivation of "general safety" training goal and course system had not gotten a wide range of employment in other industries. In addition, the economic situation improved slowly in the industry. These colleges and universities began to return from "general safety" to "industry safety".

The third stage: The development stage relying on "industry safety" and taking into account "general safety". In the development process from "industry safety" to "general safety", safety engineering discipline had gotten great development. The work declaring "safety science and engineering" as a first level discipline obtained security experts and scholars' consistent support. In this situation, the undergraduate enrollment professional directory of Ministry of Education set safety engineering discipline under the subject of "safety and environment" in 1998. At the same time, the ministry cancelled mine ventilation and safety discipline under the subject of "mining engineering". Degree Granting and Talent Training Course Catalogue approved by Academic Degrees Committee of the State Council set safety engineering discipline as a first level discipline under engineering science in February, 2011. Combined with Safety Production Law promulgation and implementation in 2002, the undergraduate enrollment institutions with safety engineering rapidly increased from the original dozens to more than one hundred. And now the number of undergraduate enrollment institutions with safety engineering has increased to 165 (the query data according to the professional recruitment schools in China Education Online). It is the problem that each university faces how to stand out in so many schools and how to make the feature. So the universities thought the specialty building mode relying on "industry safety" and taking into account "general safety" in unison.

For the third stage, some scholars also say it is the stage developing "general safety" and taking into account "industry safety". The two statements are different. From the point of professional teaching, the difference is mainly reflected on the emphasis of positioning the talents goal and installing the training curriculum system. But their general thinking is same, which incarnates the feature of the safety engineering discipline is that "general safety" is the tendency and "industry safety" is the characteristic.

During the development process of safety engineering discipline in universities, most of them have experienced three stages of development above except several ones that industry characteristic is not obvious. From the point of these stages, the students of safety engineering discipline not only need to study professional skills of safety engineering but also to understand the industry characteristics and technological process of relevant industries. Safety engineering discipline is a typical cross discipline and the safety engineering discipline talents trained by universities are also typical compound talents. In the safety engineering discipline talents training mode paying attention to the trend of development and taking into consideration school-running characteristics, making accurate positioning of the talents training target appears very important. This requires that colleges and universities must analyze the requirements of major technology ability of safety engineering and determine talents training goal based on the requirements and then make a plan of professional talents 
training. According to the feature of safety engineering discipline, a cross discipline, technical ability of safety engineering is also divided into two aspects including "general safety" technical ability and "industry safety" technical ability.

\section{Requirement Analysis of Major Technology Ability of "General Safety"}

The major ability of "general safety" is the general professional ability in all walks of life. Generally speaking, the engineer of safety engineering discipline should know within the scope of responsibilities what the main dangerous sources is, how the risk of these main dangerous sources is, how to evaluate its risk, what measures can take to eliminate or reduce the risk of these dangerous sources, how to monitor these dangerous sources and how to handle once these dangerous sources lead to accidents and so on. To be specific, the requirements of the major technology ability of "general safety" are as shown in Table 1.

Table 1. Requirement table of major technology ability of "general safety"

\begin{tabular}{|l|l|}
\hline $\begin{array}{l}\text { Category of } \\
\text { professional ability }\end{array}$ & \multicolumn{1}{c|}{ The content of professional and technical ability } \\
\hline $\begin{array}{l}\text { 1. Hazard } \\
\text { identification } \\
\text { assessment control } \\
\text { ability }\end{array}$ & $\begin{array}{l}\text { Using different methods of dangerous sources identification to } \\
\text { identify dangerous sources existing in system and engineering, using } \\
\text { qualitative and quantitative methods to evaluate risk scale of } \\
\text { dangerous sources, controlling dangerous sources existing in the } \\
\text { work to prevent dangerous sources from becoming accidents. }\end{array}$ \\
\hline $\begin{array}{l}\text { 2. Safety inspection } \\
\text { ability }\end{array}$ & $\begin{array}{l}\text { Testing and inspection common toxic and harmful gases and dusts } \\
\text { and the like. Being familiar with common safety monitoring system }\end{array}$ \\
\hline $\begin{array}{l}\text { 3. Designing ability } \\
\text { of safety technical } \\
\text { measures }\end{array}$ & $\begin{array}{l}\text { Making the corresponding measures aiming at different dangerous } \\
\text { sources according to the basic principle of systematic danger } \\
\text { controlling. }\end{array}$ \\
\hline $\begin{array}{l}\text { 4. Safety } \\
\text { engineering design } \\
\text { capability }\end{array}$ & $\begin{array}{l}\text { Knowing safety engineering design, industrial ventilation system } \\
\text { design, industrial dust removal system design, design related to fire } \\
\text { fighting, fire and explosion prevention design and the like. }\end{array}$ \\
\hline $\begin{array}{l}\text { 5. Safety } \\
\text { management ability }\end{array}$ & $\begin{array}{l}\text { Making various safety management systems and responsibility } \\
\text { system, Carrying out safety education and training at all levels, being } \\
\text { familiar with management system of relevant laws and regulations of } \\
\text { safety production and making safety supervision and inspection } \\
\text { according to these laws and regulations, having the ability of } \\
\text { handling and analyzing safety information. }\end{array}$ \\
\hline $\begin{array}{l}\text { 6. Accident } \\
\text { emergency rescue } \\
\text { ability and } \\
\text { investigation and } \\
\text { treatment capacity. }\end{array}$ & $\begin{array}{l}\text { Making accident emergency rescue plans, having the ability of } \\
\text { emergency rescue in common various work safety accident and } \\
\text { investigation and treatment production safety accidents and analysis } \\
\text { accidents. }\end{array}$ \\
\hline
\end{tabular}

\section{Requirement Analysis of Major Technology Ability of "Industry Safety"}

Actually, major technology ability of "industry safety" is the embodiment of the ability of "general safety". The requirements of safety professional ability among different industries are different because the large number of industry categories among various industries, the 
identification ways of dangerous sources existing, the types of accidents caused by the dangerous sources are different and the mechanisms for preventing accidents may also be different. Taking coal industry that the security problem is the most outstanding as an example, capability requirement is analyzed in the paper. There are five major disasters in coal mine including flood, fire, gas disaster, coal dust disaster and roof disaster. Generally speaking, mine geology department is responsible for flood disaster protection, mine production department including mining department and driving department is responsible for roof disaster control, and ventilation department is responsible for other three disasters. The main employment units of the graduates of safety engineering discipline assigned to coal mine are ventilation department, safety supervision department and rescue department in the coal mine. Especially the numbers of graduates that ventilation department absorbed is the most. So the writer believe the engineer of coal industry should have the technology ability of "one ventilation and three preventions" in coal mine (including ventilation, gas prevention, coal dust prevention and spontaneous ignition) first of all. Meanwhile, the major ability of "general safety" is necessary. From the point of large category, major technology ability of coal mine safety mainly includes safety inspection ability, designing ability of technical measures, technical data processing and analysis ability, ability of engineering design, the emergency response capacity and other professional capability, etc. according to the survey of daily work of professional technical personnel of coal mine safety. The specific major technology abilities included in each large category are as shown in Table 2. 
Table 2. Requirement table of major technology ability of "industry security"

\begin{tabular}{|c|c|}
\hline $\begin{array}{l}\text { The category of } \\
\text { ability }\end{array}$ & The content of professional and technical ability \\
\hline $\begin{array}{l}\text { Safety inspection } \\
\text { ability }\end{array}$ & $\begin{array}{l}\text { 1.Ventilation detection ability; } 2 \text {. Gas detection ability; } 3 \text {. } \\
\text { Spontaneous combustion detection ability; } 4 \text {. Dust detection } \\
\text { ability }\end{array}$ \\
\hline $\begin{array}{l}\text { Drawing up ability of } \\
\text { technical measures }\end{array}$ & $\begin{array}{l}\text { 1.mine ventilation measures; } 2 \text {.mine gas prevention and control } \\
\text { measures; } 3 \text {. mine fire prevention and extinguishing measures; } 4 \text {. } \\
\text { coal dust prevention measures }\end{array}$ \\
\hline $\begin{array}{l}\text { Technical data } \\
\text { processing and } \\
\text { analysis ability }\end{array}$ & $\begin{array}{l}\text { 1. Establishment of ventilation ten-day report. } 2 \text {. Establishment } \\
\text { of dust half-a-month report; } 3 \text {. Establishment of report relevant } \\
\text { to gas; } 4 \text {. The report relevant to spontaneous combustion; } 5 \text {. } \\
\text { Accident statistical table; } 6 \text {. Governance table of checking and } \\
\text { treating hidden risk; } 7 \text {. Safety facilities checklist; } 8 \text {. Designing } \\
\text { ability of various drawings of "one ventilation and three } \\
\text { preventions". }\end{array}$ \\
\hline $\begin{array}{l}\text { Ability of } \\
\text { engineering design }\end{array}$ & $\begin{array}{l}\text { 1. Mine ventilation system design; } 2 \text {. Gas extraction system } \\
\text { design; } 3 \text {. Specialized design of outburst prevention in mining } \\
\text { area; } 4 \text {. Outburst prevention design on extracting coal face; } 5 \text {. } \\
\text { Dust control system design; } 6 \text {. Flameproof system design; } 7 . \\
\text { Mine fire prevention and extinguishing design. }\end{array}$ \\
\hline $\begin{array}{l}\text { The emergency } \\
\text { response capacity }\end{array}$ & $\begin{array}{l}\text { 1.Emergency managerial ability; 2. Emergency technology; } 3 . \\
\text { Emergency measures }\end{array}$ \\
\hline $\begin{array}{l}\text { Other professional } \\
\text { capability }\end{array}$ & $\begin{array}{l}\text { 1. Analysis ability of mine safety production feasibility; } 2 \text {. } \\
\text { Designing ability of mine "safety special section"; } 3 \text {. } \\
\text { Construction ability of the quantity standardization of coal mine; } \\
\text { 4. Designing ability of "one ventilation and three preventions" } \\
\text { plan; } 5 \text {. Designing ability of safety production plan; } 6 \text {. } \\
\text { Calculating capacity of mine ventilation network; } 7 \text {. Checking } \\
\text { and ratifying the mine ventilating ability; } 8 \text {. Analysis ability of } \\
\text { mine ventilation system. }\end{array}$ \\
\hline
\end{tabular}

\section{Conclusions}

Aiming at the demand of training applied talents, the characteristics and the three development stages of transformation of safety engineering discipline in China are analyzed and discussed in the paper. The technical ability of safety engineering discipline is summarized as "general safety" professional skills and "industry safety" professional skills according to subject characteristics. The specific conclusions are as follows:

(1) Safety engineering discipline is a typical cross discipline. Professional talents engaged in safety engineering not only need to know technological process of the industries but also to master the law and prevention technology of accident occurrence and development. They are typical compound talents. 
(2) Since reform and opening, the safety engineering discipline have experienced three development stages of transformation which are composed of "industry security" stage, "general safety" stage, and relying on "industry safety" and taking into account "general safety" stage.

(3) The major technology ability of "general safety" mainly includes hazard identification assessment control ability, safety inspection ability, designing ability of safety technical measures, safety engineering design capability, safety management ability, accident emergency rescue ability and investigation and treatment capacity.

(4) Industry security is different because of the different industries. In general, the ability mainly includes safety inspection ability, designing ability of technical measures, technical data processing and analysis ability, ability of engineering design, the emergency response capacity and other professional capability.

\section{Acknowledgements}

The study is supported by the "study on the integrated talents training mode based on the dual needs of professional ability and professional certification "of education science research planning subject of NCIST.

\section{References}

[1] Niu Yingjian. The Analysis of the Core Capability and its Composition of the Safety Engineering Professionals[C]. Proceedings of the 2010 Chinese Seminar on the Principles of Safety Science and Technology. Beijing: Science Press, 2010. 656-660

[2] Comprehensive information inquiry system of university of China (2015-1-18).China Education Online. . http://www.eol.cn/. 